10

\title{
Europe and the French party system
}

\author{
Jocelyn A. J. Evans
}

\section{Introduction}

Since the advent of European Community/European Union politics and the growing influence the supranational arena has over domestic affairs, the potential for the European domain to impinge upon all aspects of national polities has grown. On the face of it, there has been no reason to suspect that European politics would not affect the party systems of these polities in the same way that it has affected, say, policy-making, judicial review and pressure groups. However, the effect to date has been perceived as minimal, even after the introduction of direct elections in 1979. At the comparative level, direct effects on party systems have been low: one author has commented that, '[T]o the simple question of whether Europe has had a direct impact on the format of national party systems, the equally simple answer must be an unequivocal "no", (Mair, 2000: 31).

Other authors concur with this: for instance Kitschelt consecrates little time to it in his study of evolving European party systems, and indeed argues that in particular France provides little scope for mobilisation along a European dimension (1997: 148). Similarly, Ross emphasises the encroachment of the European Union on the French domestic arena, but beyond noting the growing incapacity of governments to respond unilaterally to areas of European policy dominance and the possible explosion of mass antipathy to Europe, little time is spent on electoral competition effects (Ross, 2000).

A number of contextual reasons can be given for the lack of change: the low education of the electorate on European matters; the lack of interest in European politics; the democratic deficit that puts the bulk of European policy beyond the electoral arena, and so on. More specifically, the format of the existing party systems is often consonant with a European dimension in their ideological, if not social, format. Parties which oppose Europe are often in opposition to other aspects of the national political systems - anti-system or protest parties - and thus simply add Europe to the litany of complaints against the system (Taggart, 
1998). Leaving aside the anti-system or protest elements, other anti- or indeed pro-European stances are based precisely upon the same elements which form the foundation for domestic ideology and thus as of themselves form no basis for a shift in party system format (Evans, 2000b).

A potential source of party system change, however, derives from intra-party disagreements over Europe (Mair, 2000: 36). Parties which by necessity are often broad churches aggregating different ideological streams have been split over the European question both in terms of working within it and reaction to it. Some parties are unified in their opposition to Europe, and the French system contains examples of these. Given that for three of these parties - LO/LCR on the left, and the FN and MNR on the right - the clear anti-European stance largely mirrors their radical anti-system role in other policy domains, we will not spend much time on this for the reasons given above: such positions do not generally engender party system change. ${ }^{1}$ More importantly, the French case provides ample evidence of previously cohesive party blocs divided by the issue and, moreover, parties split - sometimes physically - by disagreements over the European agenda. In particular, the Communist Party betrays an ambivalent position to Europe, as does the moderate right. Despite their recent decline, we will devote some time to examining the MPF and RPF which were formed from splinters from the UDF and RPR respectively and which, when united in the past, threatened to become a relevant force on the right. ${ }^{2}$

However, these schisms which presented themselves in particular in 1999 have apparently disappeared in the wake of the 2002 elections. The ability of French elites to collude and to put ideological differences to one side where it is strategic to do so applies to the European issue as it does to the rest of the political arena (Hanley, 2002). However, whether or not such latent divisions prove disruptive to individual parties and to the system itself depends not just upon the ideological and pragmatic considerations of the party elites themselves, but also upon the institutional context of the system itself. Consequently, this chapter will first consider the areas of divergence within parties and party blocs, the threat they posed to cohesion and the reasons for their recent disappearance. Second, it will consider the array of institutional factors which have contributed to keeping the European issue latent within the party system, and the extent to which possible changes to the institutional structure may in future promote party system change.

\section{Partisan and intra-partisan Euroscepticism: sources and effects}

A clear indication of the divisions within blocs and parties on Europe is to be found in elite voting on the two key expansions of the European 
TABLE 10.1 Assembly votes on amendment of Article 88-2 and ratification of Amsterdam Treaty by parliamentary group

\begin{tabular}{|c|c|c|c|c|c|c|c|}
\hline \multicolumn{4}{|c|}{$\begin{array}{l}\text { Assembly vote no. } 149 \text { - amendment of } \\
\text { article } 88-2\end{array}$} & \multicolumn{4}{|c|}{$\begin{array}{l}\text { Assembly vote no. } 160 \text { - ratification of } \\
\text { Amsterdam Treaty }\end{array}$} \\
\hline Group $(N)$ & For & Against & Abst. & Group (N) & For & Against & Abst. \\
\hline PS (250) & 228 & 6 & 1 & PS (250) & 213 & 4 & $3+1$ \\
\hline RPR (137) & 109 & 19 & 4 & RPR (138) & 113 & 18 & 5 \\
\hline UDF (69) & 63 & 1 & & UDF (70) & 63 & 2 & 1 \\
\hline DLI* (43) & 42 & & & DLI* $(43)$ & 38 & 1 & \\
\hline PCF (36) & 28 & & 1 & PCF (35) & 33 & & \\
\hline $\mathrm{RCV}^{* *}(33)$ & 23 & 10 & & $\mathrm{RCV}^{* *}(35)$ & 16 & 16 & 1 \\
\hline No affiliation (9) & 4 & 2 & & No affiliation (5) & 4 & 1 & \\
\hline
\end{tabular}

Source: Assemblée Nationale website (www.assemblée-nationale.fr)

Notes: Votes do not sum to parliamentary group sizes $(\mathrm{N})$ due to absence. Changes in parliamentary group sizes due to shifts in affiliation/by-elections. Italicised PS abstention refers to Laurent Fabius, non-voting due to holding Presidency.

* Démocratie Libérale et Indépendants

** Radicaux-Citoyens-Verts

remit, namely the Maastricht and Amsterdam Treaties (Table 10.1). The Maastricht referendum of 1992 was the first time that pro- and anti-European positions cross-cut the principal axis of competition, 'uniting' extreme-left and right parties in opposition, ruling factions of moderate-left and right parties in support, and separating out the anti-European factions either in separate campaigns or in separate movements. Although held to be in part a pro- and anti-Mitterrand vote, this is the first explicit instance of the European project bringing Jean-Pierre Chevènement and his MdC, Philippe Séguin and Charles Pasqua with a separate 'no' campaign, and former PR/UDF deputy Philippe de Villiers out of the souverainiste woodwork. Within the National Assembly, the Communists were the only group against ratification in the majority. The three main party groupings - PS, RPR and UDF - were all pro-European, although in the first two a minority were against. The two former UDF adhérents Charles Millon and Philippe de Villiers within the non-affiliated group voted for and against respectively, as expected. Finally, the RCV group were split about 2:1 in favour.

Here, intra-party disparities appear in a number of ways. First, the principal left party was almost completely homogeneous - less than 3 per cent of its members voted against - together with the centre-right party of the UDF, a party which, despite at the time being neither in government nor the presidential party, was even more cohesively in favour. Conversely, 
the right wing was split, with almost 14 per cent against the wishes of its presidential doyen. ${ }^{3}$ It is fairly clear that such opposition would have come from the nationalist étatiste wing of the party. Yet the party was clearly divided, and indeed such divisions were evident in the internal party wranglings and replacement of Séguin after his resignation from the head of the 1999 European list and as general secretary of the party.

Of greater interest, however, is the major split in the gauche plurielle. As has been noted, the Communists were adamant in their rejection of Amsterdam, and there is a fundamental divide in the RCV grouping. Jean-Pierre Chevènement's MdC expressed dismay at the relinquishing of economic sovereignty, and was firmly opposed to the removal of national sovereignty in foreign and military affairs, despite the joint list with the PS and the strongly pro-European left radicals in the 1999 European elections. More appropriate, perhaps, was his resignation from the gauche plurielle government over issues of sovereignty, and his separate pôle républicain candidacy for the presidency, renouncing the Europhile intentions of the main candidates.

Given the Green Party's campaign for a 'no' vote on the Amsterdam Treaty, it is fairly clear that the Green components of the alliance also opposed ratification.

Nous rejetons ce traité qui ne fait avancer ni la démocratie ni les droits de l'homme, ni le progrès social, ni la défense de l'environnement en Europe, et qui interdit pratiquement l'élargissement. ${ }^{4}$

However, they voted in favour of the earlier amendment of Articles 88-2 and 88-4 on 1 December 1998. Indeed, looking at Table 10.1, the changes in the RCV parliamentary group are the only substantial changes between the two votes, and these are accounted for almost entirely by the shift by the six Green deputies. We would argue that, though the Greens are 'pro' Europe inasmuch as they support the supranational arena above those defined by national boundaries, they also betray elements of Euroscepticism because they oppose the rules of the game as currently defined, support of constitutional amendments permitting. For instance, opposition to the stability pact limiting budget deficits to 3 per cent 'privent [Les Quinze] des moyens budgétaires d'impulser une véritable politique de l'emploi à l'échelle européenne'. ${ }^{5}$ Similarly, the lack of democratic checks on the European Central Bank raises fears of excessive monetarism on the part of European economic policies.

This again demonstrates the need to differentiate between bases to Euroscepticism, and certainly this is not limited just to the Greens. In the case of the PCF, for instance, shifting positions on Europe demonstrate a nuancing of the party's approach to the domain. How, then, have these differences over Europe manifested themselves in the case of the main parties, and to what extent have they been resolved in the recent elections? 
PCF: from anti-system to system?

Historically, the PCF provides perhaps the greatest shift in party system role and European stance. The anti-system party par excellence since its inception and for most of its lifetime, since 1997 it found itself well established in a governing coalition with the Socialists, and in terms of Europe, as Lazar notes, '... dorénavant le PCF se veut euroconstructif' (1999: 695) ('... from now on the PCF wants to see itself as constructively European'). For the party which opposed Europe as a capitalist construct which opened workers to the perils of free market liberalism, such a change has occurred in a relatively short space of time. Under Georges Marchais, such a volte-face would have been unthinkable, yet under the reformist Hue the inevitable march of integration, and the disappearance of the alternative supranational agenda provided by the Workers' International, has - at least at the elite level - moved the PCF into a position remarkably similar to the Greens: anti-Maastricht, as Table 10.1 shows, but seeing in Europe an arena where egalitarian social policy can potentially be pursued.

La promotion sans discrimination des hommes et des femmes; la démocratie et la citoyenneté; les droits de la personne et particulièrement l'antiracisme; le respect des équilibres naturels et le développement durable; des relations internationales pacifiques équitables et solidaires ... sont autant de valeurs montantes, dans nos pays, notamment parmi les jeunes. ${ }^{6}$

Notable by its absence is an overt call for economic dirigisme. Free market liberalism is held to be in crisis - 'Le mythe du capitalisme triomphant se dissipe' - but no alternative is provided, beyond vague references to a renewed role for the $\mathrm{EU}$ in international economic relationships.

Consequently, the emphasis of Bouge l'Europe! - the Communist-led list in the 1999 European elections - on social rather than economic factors, the famous double-parity list combining a non-Communist for every Communist, and its particular targeting of younger, socially aware voters brings it firmly into the moderate camp, most of these items being no more radical than the declared aims of European Social Democratic parties. Certain existing aspects of the EU institutions are challenged for instance, the Schengen Agreement is seen as pernicious, particularly for the economically less anchored Mediterranean member states, and thus the protection of national borders is called for in rather more traditional Communist style - but it would be difficult to promote the PCF agenda as any more radical than the Green agenda.

In systemic terms, then, should the PCF now been seen as avowedly pro-European? We would answer 'not yet'. Three factors determine this response. First, the results of the European elections showed an essentially stagnant result, dropping -0.12 per cent from 1994, and at the national 
level the failures in the 2002 elections have emphasised this trend. The new Euroconstructive slant has hardly proved its worth in pulling in new electoral pools. As Bell surmises in his consideration of the strategic options now open to the PCF, this does not mean that it will immediately renounce such an agenda and return to dogmatic opposition (see Chapter 2 of this volume). However, two particular electoral dynamics which contributed to this unmoving electoral score in 1999 underline that the PCF must make some effort to regain its hard-line, anti-European voters.

First, Dolez notes that a number of Pasqua voters of 1999 came from Hue's 1995 presidential electorate (1999: 665); and Lazar notes that the PCF was beaten by its extreme Trotskyist rivals LO-LCR in many big towns, and in former bastions, such as Seine-Saint-Denis and Pas-de-Calais, the Communist lead over the Trotskyists has been eaten into (1999: 703-4). Undoubtedly, the Pasqua voters, although few in number, are evidence of former PCF voters disenchanted with the new soft touch on Europe; similarly, the Trotskyist defectors are disenchanted by the abandoning of a hard-line agenda more generally. A similar centrifugal dynamic pertained in the 2000 presidential elections, although clearly Hue's losses could not be accounted for by moves to Pasqua or de Villiers, neither of whom stood in the elections.

Such shifts are not a surprise, and the second factor to note: in 1997, the PCF electorate remained very strongly anti-European, with almost 60 per cent declaring that they would be relieved by the collapse of the EU (Evans 2000b: 550). Such centrifugal electoral dynamics are occurring at the expense of electoral support which was replaced in the 1999 elections by a number of former non-PCF voters in zones of previous weakness (Lazar, 1999: 704). ${ }^{7}$ The success of appealing to the younger socially aware elements was clearly undercut by Daniel Cohn-Bendit's stronger appeal to this pool. As such, the PCF has to decide whether to continue to try to recruit this electorate - younger, new voters appealed to by the other, more traditionally libertarian parties of la gauche plurielle and even by a more socially liberal UDF - or whether to stick with the tried and tested - older, established voters with only abstention and the minority appeal of LO-LCR as alternatives.

Third, at the elite level there is evidence that the new pro-European line is not yet firmly established. The clearest evidence of this was during the Kosovan crisis when many of Bouge l'Europe!'s candidates supported European intervention in NATO, including Geneviève Fraisse, who held the number-two slot on the list, and Philippe Herzog the rénovateur. The Communist Party, however, opposed it. Undoubtedly, much of the opposition derived from US involvement and perennial concerns of imperial hegemony. However, as part of the EU's common foreign policy, such opposition together with other European Communist parties does not bode well either for Communist support of and 
participation in the European project or for future collaborations in double parity lists.

To refer to Chapter 2 again, the position of the party's ideology depends very much upon the role it decides to (try and) play within the system and consequently the extent to which it distinguishes itself from the dominant partner. The fault lines between the MdC, the Greens and the PS within the government demonstrated the extent to which left homogeneity is far from being a given. Moreover, as Andersen and Evans demonstrate in the following chapter, there is no evidence of growing homogeneity among the left electorate either. The possibility of future PCF antagonism can still not be ruled out. As such, the Communists may still be potential incumbents in the anti-system camp. However, the PS's need for a partner on the left and the Communists' desire to retain the possibility of future governmental participation means that the more 'obvious' strategic option is to try to contribute to a rebuilt gauche plurielle and rein in its criticisms on Europe and elsewhere, rather than return to the extreme fold where competition is now much stronger but less rewarding.

\section{Pasqua - de Villiers and the MPF/RPF}

Prior to de Villiers's departure from the RPF, it would have been impossible to conceive of the formation of this movement without the existence of a European dimension. From de Villiers's decampment from the pro-Maastricht UDF in 1992 to lead his own Combat pour les Valeurs and subsequently MPF, the internal divisions between pro- and anti-European members of both the RPR and the UDF became increasingly prominent, to the extent that the Pasqua-Séguin tandem who campaigned for a 'no' vote in the Maastricht referendum of 1992, had both departed by the European elections of June 1999, Pasqua to present a joint list with de Villiers, Séguin simply to resign both list and party leadership.

While the intra-party splits in the UDF and RPR are themselves of interest, and considered in the following section, the formation of an ultra-conservative droite souverainiste manifests a separate dynamic on the right. As Ivaldi notes in his assessment of the performance of the Rassemblement pour la France et l'Indépendance de l'Europe (RPFIE) in the 1999 elections (1999b: 651) the party and its electorate in the domestic arena are undoubtedly legitimist and represent the traditional bastions of conservative right-wing support in France. Older, male, petty bourgeois and agriculturally based, the electorate does not differ substantially from the traditional core support of the RPR (Ivaldi, 1999b: 643). Its score of 13.1 per cent represented the dual positive effect of the proportional electoral system combined with the importance of charismatic heads of the national-constituency lists. However, the elections also represented the first time since the onset of the third period of 
cohabitation that the Eurosceptic right-wing electorate was able to demonstrate its discontent at the national level, the need for a homogenised right vote in 1995 and 1997 being of perhaps a higher priority, and indeed the issue being kept off the agenda by the mainstream parties precisely because of its divisive nature. Undoubtedly, Séguin's resignation due to interference from an increasingly Europhile president and his RPR minions sealed the mass electoral defection to the Pasqua-de Villiers movement.

The French partisan pathology of leadership rivalry has seen de Villiers's subsequent departure, and Pasqua's greater desire for cooperation with the moderate right-wing neighbours may seem to indicate a return to at least allied unity, if not a united conservative right. The latter's withdrawal from the presidential race, ostensibly over doubts as to whether he could collect the requisite five hundred signatures for his candidacy, cost the RPF dear as did de Villiers's absence for the MPF. The parties' reliance upon leadership prominence and their relatively short existence meant that the absence of both of the droite souverainiste candidates from the presidential slate deprived them of vital campaign exposure. Moreover, an effective separate presence in the 2002 elections was hampered by the inability to present a national slate of candidates.

Thus, in second-order European list elections, the party can mount a serious bid to winning seats, but at the elections which count, a return to marginality is almost inevitable. This is not helped by the presence of two such parties, although the ageing Pasqua must soon leave the path open to de Villiers alone. A combination of party split, an absence of positive leadership coverage (Charles Pasqua featuring mostly in the 'arms to Angola' affair), the focused nature of regional support allowing de Villiers's election as deputy but winning only 0.8 per cent of the nation vote, and the omnipresent strictures of the institutional framework have seen the two parties almost vanish from the political map in the space of two years.

On the basis that Pasqua's political career is effectively over, only de Villiers can hope to re-establish his party, and, given the growing salience of the European issue, a likely strategy would be to use this to criticise pro-European governments either of the left or of the right. Much depends on the fortunes of the RPF's neighbours, the FN and the UMP. Looking first to the extremes before considering the moderate right, the schism in 1998 certainly provided added support for the RPFIE in the 1999 European elections. Le Pen's success in 2002 and the relatively small decline of the $\mathrm{FN}$ vote in the legislative election provides a less auspicious context for either the MPF or RPF to pick up disenchanted support from its right. Indeed, the lack of deputies for the FN seems likely to consolidate protest support in this party given the 'injustice' of the system which fails to allocate any seats to a party with 12 per cent 
of the vote. However, the age of Le Pen and the threat of fresh internecine rivalry, this time between his daughter Marine and the party number two Bruno Gollnisch, could leave the FN unable to hold onto much of its support. In a context of anti-European support, the MPF could provide an alternative representative. Similarly, a pro-European presidential party could lose Eurosceptic support in the same direction.

\section{A widening gulf between UDF and UMP?}

In many ways, the split over Europe which occurred in presenting separate lists in the 1999 elections simply highlighted one of the remaining ideological divisions between the two moderate-right parties. ${ }^{8}$ The UDF being more socially liberal on its CDS wing, more economically liberal on its PR side, the RPR's cooperation with their federal neighbour was an example of intra-bloc strategy par excellence in the French institutional setting. Since the mid-1980s, there has been an element of ideological convergence of the two organisations - the PR was heartened by the RPR's conversion to market economics, even if it was half-hearted; similarly, the CDS wing saw greater proximity with the same party's conversion to Europhilia, even if this were even less well-founded for many Gaullists (Machin, 1989: 65).

However, the half-heartedness of such changes merely reflected divisions within the UDF itself, with the eventual split of Alain Madelin's DL - a more successful partner for the RPR in recent times - and the unification of the UDF into a single party after the CDS's conversion to FD by François Bayrou. Until this point, however, the party's prominent role in European matters within the moderate-right bloc had given it a purpose which the loss of its role as presidential party for Giscard d'Estaing had denied it. In the early years of integration, it provided the head of the moderate-right lists in 1984, 1989 and in 1994, the first election subsequent to the 1992 Maastricht acceleration of the European project, and the consequent departure of de Villiers from the UDF.

Similarly, the RPR's internal ideological splits had remained muted or channelled via internal struggles of notables until the manifestation of divisions over Maastricht. By the time Amsterdam and subsequently the European elections had arrived, precisely the proximate point to the RPR within the UDF - DL - had already split off. Even with Séguin's resignation, Bayrou and his party felt unable to join in a combined list, perhaps out of a certain resentment towards the UDF's Senate betrayal in the RPR successfully fielding Christian Poncelet for the presidency against their incumbent Monory, certainly against the RPR's chaotic response to the regional presidency debacle of 1998, but primarily over the UDF's demands for an EU endowed with a range of sovereign, legitimised institutions which could not have stood the test of proximity with the RPR's divided views (Bréchon, 1999: 654). 
The European dimension has also played two roles in electoral competition terms. First, as we have seen, it has acted to sap both principal members of the moderate-right bloc, both parties losing support to the RPF in 1999 (Bréchon, 1999: 659). Second, the stability of intra-bloc voting has been challenged further, with the RPR losing its centrist electorate to the UDF - an electorate which furthermore had shown its affinity with the UDF in their common support of Balladur in 1995, and regionally in its clear approval of Maastricht. With the split between the parties entrenched in part on the European dimension, some commentators saw this as a means for the UDF to challenge the Gaullist hegemony within the moderate-right bloc (Dolez, 1999: 663). Given the unification of RPR, DL and the bulk of the UDF into the UMP, however, such a challenge to hegemony in the short term is untenable. But the UDF still has an incentive to emphasise the differences between it and its hegemonic neighbour if only to underline its right to a separate existence. Clearly, the European dimension is one area for such delineation.

In terms of Europe, the UDF is certainly closer to its moderate-left neighbours than to the Gaullists (Dolez, 1999: 671-2). If the UMP continues to fail to produce a stronger line with less anti-European sniping, this may produce one factor reallocating support from the UMP to the UDF. Furthermore, prodigal UDF deputies who decamped to the UMP in the elections may well find their way back to Bayrou's party without threatening the overall stability of the moderate-right government. In economic terms, the departure of DL had already lessened the divide between the UDF and the PS as well - acceptance of the market and monetarist rigour to stay within EMU bounds are both examples of policies espoused by both parties. The likelihood of a broaching of the centre is minimal - Bayrou's desire for an autonomous centre-right for strategic reasons renders the possibility of any such alliance at the national level impossible in the short term, and the electoral consequences of abandoning the traditional bloc would in all likelihood be disastrous. However, the proximity does mean that the UDF is ideally placed to compete with the PS for centrally located voters. A PS hampered in a gauche plurielle opposition in providing a clear line on Europe, for example, could see a critical but governing UDF pick up pro-European support at a later date.

As we have seen, one of the principal reasons that the European dimension has not had a greater effect on the party system is that its proponents have been thwarted by the institutional rules of the game. The two-bloc majoritarian straitjacket reduces the effectiveness of alternative agendas as a means of attracting electoral support either to bolster flagging scores or to encourage new formations - the principal left-right axis of competition remains the only game in town, and the European dimension only wins support when it mirrors the traditional axis. An 
implication of this is that changes to the institutional structure could allow a greater saliency to the European dimension at the national level. We turn now to the possible institutional changes in the French context and their likely effects.

\section{Institutional context}

We would posit three institutional factors as providing the framework determining the effect of the European dimension: the different levels of election; the electoral system at the presidential and legislative levels; and the presidential mandate and its recent emendation. To date, these have ensured continuity in the party system. However, changes in these increasingly threaten such stability.

\section{Electoral levels and the 'electoral accordion'}

As most voters would attest, France has a bewildering array of elections, including three at the national level - presidential, legislative and European - as well as a series of sub-national ballots. Many commentators have noted that, in recent years, the party system at the sub-national level has displaced itself from the national pattern. A number of factors have been responsible for this: the 'personality' politics at the local level; the lower stakes of a sub-national ballot; the electoral system using proportionality rather than a majoritarian system. Perhaps the most explicit example of this was the UDF regional presidents relying upon FN support to retain their presidency, thus forging de facto coalitions, if not outright alliances. Such legitimation has been fought against at the national level not for reasons of ideology or political correctness, but due to the increased electoral threat this poses to the moderate-right parties. At the local level, such desperate measures by Millon et al. are illustrative of the importance of the local power base over broader long-term considerations for the party. The internal wranglings in the UDF over this affair was in no small part responsible for the subsequent break-up with DL leaving the party after a less than condemnatory attitude towards the matter, and a more critical FD remaining within the newly unitary UDF. ${ }^{9}$

Such disparity between party system dynamics at different electoral levels is also present at the European level. Again on the right, the Séguin-led Eurosceptic RPR list was anathema to the UDF's pro-European equivalent. As we noted in the introduction, such divergence under Parodi's 'electoral accordion' (Parodi, 1997), which expands under PR systems to allow greater fragmentation, and contracts for the two-ballot systems, cannot go without certain osmosis between the levels. Parties which compete at other levels must find it increasingly difficult to reconcile 
differences they have emphasised to form alliances later on. The first ballot allows a certain level of fragmentation, but at the second, can competing parties which have previously differentiated themselves credibly support their difficult neighbours, or from another perspective, safely rely upon their support? The resolution of conflict between UDF and RPR derived not from any ideological shifts but by the simple expedient of a massive electoral imbalance in 2002.

In the past, 'better them than the other side' has been a powerful logic. Yet, under the apparent convergence which all European systems are undergoing, 'the other side' no longer constitutes the Communist or reactionary threat that it once did. In a system increasingly enmeshed with the European level, can parties which oppose each other vehemently on the nature of this arena forge unconvincing alliances, when, to their opposite side, a party with greater consonance on these and other matters is present? This logic is especially important for the UDF sans DL and the PS. Rocard's openings to the CDS may have failed in the early 1990s, but the mere fact of trying demonstrates its potential. When institutional incentives change, new dynamics can appear from parties who dare and both the first-order electoral system and the bipolar presidential logic seem set to change in the future.

Post two-ballot majoritarianism?

While ever the two-ballot majoritarian system pertains for both legislative and presidential elections, the overriding logic will be for competing parties to try to form blocs, which, although riddled with internal divisions and personality rivalries, can at least command 50 per cent +1 at the second round. While triangular ballots have become more common, the two-candidate run-off for legislatives is still by far the norm, and for presidentials the rule. To this extent, many authors have been right to characterise the party system as being sustained in its traditional format. However, we believe that the existing tensions highlighted above are at least as important in demonstrating the potentially fragile state of the party system which in the late 1990s seemed only supported by its institutional structure. The 2002 outcome may have reduced fragmentation and re-emphasised the logic of bipolar alternation, but the plethora of presidential and legislative candidates and the radical stances of many of these cannot be ignored. Under different electoral rules, their influence can become more difficult to contain.

Threats to presidential power come from the quinquennat (see below). The main threat to the legislative elections comes from the left, where the Greens among others are pushing for a level of proportionality to be introduced into the electoral system. As Villalba and Vieillard have shown in Chapter 4 of this volume, Green factions such as Autrement les Verts and Ecologie et Démocratie have been highly critical of the 
national leadership for not pressuring the Socialists for electoral reform by 2002. Granted, such electoral reform was unlikely in the very short term under the Socialists and seems similarly unlikely under the UMP, despite declarations to the contrary. In terms of promoting democracy, the right has followed the left's lead in putting decentralisation at the top of the agenda.

However, in any reconstruction of the gauche plurielle, one of the key elements which the Greens will undoubtedly push for, if they are to join in a new common programme, will precisely be electoral reform to include a dose of proportionality in the legislative elections. If this occurred, the rebalancing of seats among the parties would give greater influence within the policy-making arena to precisely those parties which take a Eurosceptic line but which at the moment are marginalised or absent from the legislature.

\section{Presidential shifts}

The third aspect to be considered - and, despite being an actuality, still an unknown quantity - is the shortening of the presidential mandate to five years. Again, we would emphasise that this amendment alone will not inexorably lead to a change in the party system. Indeed, many of the arguments in favour of the quinquennat imply precisely the opposite. Following Olivier Duhamel's arguments, ${ }^{10}$ for example, the shortening of the mandate will reinforce presidential efficacy by making cohabitation less likely and thus providing concurrent five-year terms for president and presidential party alike. The relevant factor to note here is the effect that the quinquennat will have on the reserved presidential domain. In terms of Europe, the arena - as opposed to the issues - has remained to date very much within the presidential domain first, and then under governmental remit where a president feels fit. Granted, under cohabitation, prime ministers have attempted to impose themselves on the European stage, Lionel Jospin perhaps enjoying the greatest success in international relations more generally, but the reserved domain and the independent mandate have ensured that the president's primacy has not been challenged. If Duhamel is correct, and the 'president + government' governing team is held accountable once every five years, then it is difficult to see how the former can prolong the pretence of his/her role as the neutral arbiter above party politics.

If this is the case, then the president's current unique role in foreign affairs must be questionable. Whatever Duhamel's constitutionalist arguments for the greater accountability of the president, it cannot follow that the president will be able to withdraw from the domestic arena in the way that Mitterrand managed, and thus the two domains will be inevitably brought closer. It takes little insight to see that with the ever closer European arena mentioned above, these domains will be even 
more closely linked. With 'foreign' affairs increasingly impinging on domestic affairs, the separation of domains will become increasingly untenable and unwanted. As such, presidential candidates within parties will have less opportunity to use these latter as their electoral support groups at one moment, and then ostracise them the next, any more than a prime minister is able to do this in a parliamentary system.

For the moment, Chirac's honeymoon period is allowing him to manipulate domestic policy, and fairly explicitly - the name of the new right-wing party emphasises that the governmental majority is a presidential one, as if this needed emphasising. However, the longer-term implications of such a tightening of the two branches of the executive must demand a revisiting of the head-of-state role which itself demands a veneer of neutrality. Whether the republican electorate which renewed Chirac's lease on the Elysée for another five years will support such political domination of foreign affairs remains to be seen.

\section{Conclusion}

The elements of continuity in the French party system, to which we will return shortly in the conclusion to this book, are deceptively powerful. In the 1999 European elections, the fragmenting forces at work on the right and the intra-coalition bickering on the left seemed to place the system on the edge of a fundamental crisis. Granted, not all of these divisions were based upon the European issue, but this issue did seem to be increasingly dividing a governing and opposition elite both from extremist elements and from factions within the mainstream itself. Moreover, a majority of votes in the presidential first round were won by Eurosceptic candidates. By 2002, such divisions seem to have returned to obscurity almost entirely. But the elements mentioned above emphasise that the latent support for Eurosceptic feeling against the predominance of pro-European incumbents remains and that, in the correct context, it can reveal itself as a powerful force within the French system.

Though we can at best speculate as to the future changes in the institutional context, the presidential quinquennat is one aspect which must inevitably change the executive relations with Europe and thus may well affect presidential candidate - party relations and by extension the party system. If nothing else, an unpopular president trying to assert the monopoly of a European role characteristic of the septennat may precisely find vituperative Eurosceptic opposition decrying the railroading of France into ever deeper integration. However, it seems likely that some toilettage institutionnel will take place (Le Gall, 2002: 43) and to the extent that many of the fundamental changes to date have responded to the European arena, so it is likely that future changes will follow the same pattern. 
Indeed, this gives a clue to the steadfast inability of the European 'issue' to assert itself in party competition and within the national party system. The nature of Europe as an arena means that its effects are seen more through the processing of other issues in terms of policies, treaty ratification and the like than as a separate issue by itself. Despite increasingly encroaching upon the national arena, the saliency of Europe can be seen more in its effect on the traditional elements rather than in the introduction of a new element per se. In terms of the party system, then, the parties are increasingly functioning within an arena defined by Europe, rather than competing in a system on the issue of Europe. Only when adjustments to this arena are made, for instance in terms of the Maastricht and Amsterdam Treaties, does Europe become an issue in the common sense of the word. However, the examples we have given in this chapter demonstrate that, when such an issue does raise its head, the latent oppositions within and between parties on this question are sufficiently entrenched to provide for potential change. That such change to date has not occurred illustrates the strong currents of continuity within the system itself rather than the irrelevance of Europe.

\section{Notes}

1 For an account of FN opposition to Europe, see Benoît (1997, Ch. 2), Evans (2000b).

2 Saint-Josse's Chasse Pêche Nature Traditions is another party of the right which has limited first-order electoral support, despite winning 6.8 per cent of the vote at the 1999 European elections (all European election figures in this chapter are taken from the special feature on the European elections in ECPR News, autumn 1999). As an effectively irrelevant party at the national level, we will not spend any time on it. Similarly, the decline in the MdC of Jean-Pierre Chevènement has effectively ended this group's influence in the system.

3 Interestingly, Philippe Séguin, one of the principal antagonists in the 1999 right-bloc split, voted 'yes' to the Amsterdam Treaty.

4 Les Verts, communiqué de presse, 2 January 1998; 'We reject this treaty which makes no advances in democracy, in the rights of man, in social progress or in the defence of the environment in Europe, and which effectively rules out expression'.

5 Les Verts, communiqué de presse, 17 June 1997; 'deprives the fifteen member states of the budgetary instruments required to drive an effective employment policy at the European level'.

6 'Appel commun pour une nouvelle voie de la construction européenne', European Communist Parties, June 1999. Taken from PCF website (www.pcf.fr/europe/une.html); 'The promotion of men and women without discrimination; democracy and citizenship, the rights of an individual, and particularly anti-racism; the respect of nature's balance and sustainable 
development; peaceful and fair international relations based on solidarity ... these are the kind of values which today are spreading across the country, particularly among its young people'.

7 Indeed Lazar notes that these dynamics are also affecting the PS in some areas (1999: 705).

8 As Knapp and Sauger note, perhaps organisational differences between the two parties are one of the fundamental reasons for separation of the components, militating against the desire for a single moderate-right actor among many of its electorate (Sauger, Chapter 7, this volume, Knapp, 1999: 117 and Chapter 8, this volume).

9 See Sauger, in Chapter 7, this volume on this point.

10 Taken from the PS website (http://www.parti-socialiste.fr). 